\title{
LITERARY JOURNALISM. PUBLIC SPEECHES. BIBLICAL MOTIFS
}

\section{Oleg Kharchenko}

Associate Professor at the Institute of Journalism, Borys Grinchenko Kyiv University, Ukraine e-mail: ov.kharchenko@kubg.edu.ua, orcid.org/0000-0002-6263-4573

\section{Summary}

This article focuses its attention on the functioning of the biblical motifs in American fiction and their penetration in American public speeches and non-fiction through literary journalism techniques.

The findings of this work illustrate that biblical motifs and religious lexicon as a whole have been used steadily in the speeches of all U.S presidents. Taking into account that the majority of Americans (73\%) relates to Christians, the biblical motifs belong to important rhetorical and stylistic tools of all U.S. presidents in their search for the support of voters.

Since Ronald Reagan (1981-1989), there has been an apparent tendency to employ more religious words and biblical motifs. The most active users of them were Donald Trump, George H.W. Bush, and Barack Obama who applied 7.3, 4.8, and 4.1 religious words per one thousand in their speeches.

While monitoring the biblical motifs in American mass media and multimedia, we identified the most periodically applied: God, All-Mighty, Lord, Supreme Being; Satan, Devil, Lucifer, Beelzebub, Baphomet; Saint Mary; Archangels; Angels; Four Horsemen of Apocalypses; The Three Wise Men; Messiah, the Chosen One; All-loving hero; Cain and Abel; Samson and Delilah; False prophet; Nephilim, giants.

According to our findings 136 names of angels were determined in American fiction and non-fiction. As for the theological angels, whose names differ sometimes, their number is 123. The total number of Archangels, mentioned in America mass media, is 17. However, in the Bible and Enoch book just only seven archangels are named.

The research results could be used by the specialists in media studies, journalism and philology, as well as by practical journalists and multimedia authors, including Ukrainian students, who plan to sharpen their skills in writing English content.

Keywords: literary journalism, Biblical motifs, motif, religious words, rhetoric, stylistic figure.

\section{DOI: https://doi.org/10.23856/4905}

\section{Introduction}

In such religious country as the USA, the Christian religion is dominant, with more that $73 \%$ (Newport, 2017) of the present-day citizens, according to various sources, claiming affiliation with Christianity. Practically, all presidents of the USA used such phrase as "God bless America" in their speeches. The Biblical motifs permeate all spheres of the civil life of this country. American fiction and non-fiction are not exceptions in this regard.

The main objective of this work is to afford deeper insights into the biblical motifs functioning within the frames of American fiction, non-fiction, its constituent - literary journalism, public speeches, stylistically closely connected with non-fiction. To achieve this goal, the following tasks should be carried out: 
- to monitor American fiction, non-fiction and public speeches and to single out the Biblical motifs;

- to analyze and to classify the Bible motifs from American fiction, non-fiction and public speeches;

- to outline the perspectives of the study of motifs in general and Biblical motifs in particular and their employment in non-fiction and its constituent - literary journalism.

The methods of research: empiric research, monitoring of mass media and multimedia content, classification, content analysis, stylistic analysis. We will consider the proliferation of biblical motifs from the 'literary journalism' perspective. This journalistic trend was launched in the 1960s in the USA. It was defined as "as a form of nonfiction that combines factual reporting with narrative techniques and stylistic strategies traditionally associated with fiction. This form of writing can also be called narrative journalism or new journalism" (Nordquist, 2020).

Some researchers affirm that the term 'literary journalism' is a "highly contested term" applied in the meaning of creative non-fiction, literary non-fiction, narrative non-fiction, the literature of fact, lyrics in prose, gonzo journalism, long-form journalism, slow journalism, multi-platform immersion journalism (Keeble, 2018). Adding that "most analysis of literary journalism is keen to stress the quality of the techniques deployed..." (Keeble, 2018).

While comparing American and English literary journalism histories, John S. Bak, the first President of the International Association for Literary Journalism Studies, underlines the difference of traditions and 'many strands': "Since journalism in America and in Europe evolved from different traditions, it is only natural that their literary journalism should have done so as well. But the picture of a U.S.-led literary journalism and a European-produced literary reportage is not as clearly demarcated as one would think or hope" (Bak, 2011:11).

According to our hypothesis, the term 'literary journalism' reflects the process of the gradual penetration of literary devices and stylistic figures in various types of journalistic works.

The important contribution to the development of all issues connected with this trend was made by M. Lawson (Lawson, 2008), T.Wolve and E.W.Johnson (Wolve, Johnson, 1975), who thought that literary techniques of some prominent authors like T. Smollett, A.Chekhov, H. Fielding. C. Dickens, E. Hemingway, H.de Balzac, outlined the evolution guidelines of American literary journalism. Among numerous literary tools they highlighted the significance of the third person narrative, dialogue, strict time chronology, and status details.

\section{The Biblical motifs and their types}

Among other literary tools, motifs belong to important ones, gradually saturating nonfiction mass media and multimedia areas. From a traditional point of view, "a motif is a literary technique that consists of a repeated element that has symbolic significance to a literary work" (Gladwell, 2021). It could be a repeated image or sound, a word or phrase, an action or situation, a color or smell, etc.

Writers make motifs to cast key themes, to tune audience in a necessary mood, to set up symbolic meanings, to structure the flow of ideas.

In contrast to symbols, mentioned just once in a novel or story, motifs must make scenes repeatedly. In opposition to themes, motifs are smaller aspects of themes, underlying themes with recurrent symbols or images, words or phrases. For example, if the story`s key theme is happiness, the motifs could be exposed through the following actions and emotions: the protagonist could feel on cloud nine while seeing his wife or girlfriend; could be tickled pink while winning some great prize; could walk on the air while getting a long-awaited goal, etc. 
As for such term as 'genre', we understand it as the category of fiction and non-fiction, in written or spoken, audio or visual forms, meaning some speech model, based on some culturally determined stylistic features.

The Bible has influenced the world literature since the old times. The Biblical motifs belong to the recurrent ones in American and British literature. It is hardly to overestimate the influence of Bible on the development of the whole humanity. We start our brief overview of the different types of Bible motifs applied in fiction, non-fiction and public speeches.

\section{God, Lord, Supreme Being, All-Mighty}

The central figure in literature with biblical motifs is God. In 'Paradise lost' by J.Milton, God is portrayed as the powerful antagonist of Satan: "What in me is dark

Illuminate, what is low raise and support,

That to the height of this great argument

I may assert eternal Providence,

And justify the ways of God to men." -Book 1, Line 22-26 (Milton, 1667).

The Biblical motifs, based on God and prayers to him, are applied in feature articles and speeches of the prominent politicians of the USA and Great Britain. During the election campaign, in the response to the allegations of Donald Trump, Joe Biden responds: "And in this moment of darkness for our country - of pain, of division, and of sickness for so many Americans - my faith has been a guiding light for me and a constant reminder of the fundamental dignity and humanity that God has bestowed upon all of us" (Forgey, 2020).

Such researches as K.Coe and D.Domke affirm that the application of religious rhetoric by high-rank politicians, including presidents, is the principal practice "to signal and maintain close ties with a societal faction"(Coe, Domke 2006). While using the biblical motifs in particular, and religious lexicon as a whole, top state officials follow two main communication tactics - informing and persuading the public.

The first American President George Washington in his inaugural speech delivered in 1789 offered "fervent supplications to that Almighty Being who rules over the Universe" (Peters, 2018). It is obvious that since G. Washington the phrase "God bless America" became de rigueur for all top American state officials.

The Biblical motifs sound frequent in the speeches of President Barack Obama: "I pray that we will uphold our obligation to be good stewards of God's creation - this beautiful planet. I pray that we will see every single child as our own, each worthy of our love and of our compassion. And I pray we answer Scripture's call to lift up the vulnerable, and to stand up for justice, and ensure that every human being lives in dignity" (Leiro, 2016). Biblical motifs, including God, intensified with such stylistic devices as anaphors (I pray...I pray...I pray...), Biblical metaphors (Scripture`s call), metaphors (good stewards, lift up the vulnerable) and isocolon, make this speech passage very powerful.

Donald Trump inserts Biblical motifs in his speeches quite often too. While giving an interview from the hospital treating his COVID-19, he said that doctors "look like miracles coming down from God" (Hughes, 2020). While mentioning the Christian God we see that D. Trump uses such lexical units as 'Lord', 'God', 'Supreme Being.'

Such researcher as C. Hughes affirms that D. Trump uses 7.3 religious terms per one thousand words of speech - that has been the highest rate among all presidents of the USA since 1933. According to his survey and content analysis we can compose the following tablet: 


\section{American Presidents and religious words in their speeches}

Tablet 1

\section{Percentage of religious words in speeches of American Presidents per one thousand based on Chart: The Conversation CC-BY-ND International Journal of Communication (Hughes, 2020).}

American President Religious words per thousand in speeches American President

Franklin D. Roosevelt

Religious words per thousand in speeches

3.8 Jimmy Carter

2.6

Harry Truman

2.8 Ronald Reagan

4.1

Dwight Eisenhower

2.7 George H.W. Bush

4.8

John F. Kennedy

1.6 Bill Clinton

3.7

Lyndon B. Johnson

3.6 George W. Bush

3.9

Richard Nixon

2.2 Barack Obama

4.1

Gerald Ford

2.5 Donald Trump

7.3

From this tablet we see that, starting from Ronald Reagan (1981-1989), the modern American presidents use the religious lexicon more often than the previous Presidents of the USA from 1933 till 1981.

\section{Satan - Lucifer - Beelzebub- Baphomet}

The biblical motif of the antagonist of God has been employed in the world literature for thousands of years.

In the short story named 'Flies' (Azimov, 1953), three college friends meeting each other twenty years after, discuss the pun from Hebrew 'Ba'al zevuv' meaning 'Lord of the Flies.' Two of friends are chased by clouds of flies, but the third is not. The hint is made that he turned into... Beelzebub.

In 'Paradise Lost' (Milton, 1667), an epic poem, Satan (Lucifer) is portrayed in a very detailed and ominous way. As the leader of fallen angels, he moves to Pandemonium, the capital of Hell, and calls all dark forces to unite for the fight against God and his followers. His top aides are Beelzebub, Belial, Mammon and Moloch. The first victory of Satan is the penetration to the paradise garden and the seduction of Adam and Eve with the apple of knowledge.

In 'Return to House on Hinted Hill' (Garcia, 2007), a horror film, Baphomet, presented as a powerful demon sculpture, plays the role of MacGaffin (an object motivating characters 
to fight for it). It is a triple-horned, back-winged and goat headed creature. It inspires angst, anxiety and awe.

In his famous speech, called by journalists as 'Evil Empire Speech' Ronald Reagan called the former USSR as "the focus of evil in the modern world" and "evil empire," affirming that the world witnessed the battle between good and evil (Reagan, 1983). The application of antithesis mixed with Bible motifs turned out to be moving and memorable.

In August 2016, in his speech about Bernie Sanders, Donald Trump mentioned his main opponent Hillary Clinton: "If you would have just not done anything, just go home, go to sleep, relax, he would have been a hero. But he made a deal with the devil. She is the devil. She made a deal with the devil. That's true" (BBC, 2016). While calling H.Clinton 'the devil' three times, D.Trump resorted to the biblical motif of Satan, applying such stylistic figures as diacope (repetition), isocolon (just go home, go to sleep) and antithesis (hero / devil). However, such communicative tactics of the affront is not desirable from the moral point of view because the 'Law of Boomerang' works.

\section{Archangels}

The biblical motifs connected with archangels are based on seven archangels described in The Bible and several more archangels the names of which are mentioned in earlier Christian and Jewish sources. The main four archangels are Michael, whose name means 'Who is like God?'; Gabriel, translated as 'the strength of God ' or 'the hero of God'; Raphael, whose name says 'God's healer'; Uriel whose name translates as 'Fire of God.' The other three archangels, mentioned in the book of Enoch, are called Raquel ('Friend of God'), Zerachiel ('God's command'), Jeremiel ('Thunder of God' or 'Mercy of God').

In Jewish tradition archangel Metatron is mentioned more often among several additional archangels. His name means, 'Name like his master' or 'the one next to the ruler.' Besides, we can come across several more names of Archangels (Azrael, Chamuel, Haniel, Ariel, Zadkiel, Jophiel, Raziel, Sandalphon, Barachiel). According to our research, the total number of archangels in American mass media is 17.

In 'Paradise Lost' (Milton, 1667), an epic poem, readers see Archangel Michael having tense discussions with Lucifer. Archangel Raphael warns Adam not to eat the apple from the tree of knowledge. Archangel Gabriel is described as the chief of all angelic guards protecting the paradise. He has a special horn to call all God`s forces. Archangel Uriel defends the Sun and the gates of Earth from evil forces; however, he was misled by Lucifer flying to the paradise.

In 'The Last Trump' (Azimov, 1955), a sci-fi short story, Archangel Gabriel declares the Day of Resurrection, when all the dead come back to life, and in such a way the end of Universe starts. Though, thanks to Etheriael, young seraphim, he stops doing it because of the evil deeds of R. E. Man, which sounds like 'Ahriman' or the Persian name of Satan. The world starts its normal functioning.

At political debates archangels, as biblical motifs, are mentioned by American politicians from time to time: "Mr. Palmer. What, that we have not any archangels there? I did not know that you thought that we had. You seem to think that judges down in your country are archangels or made of a different kind of mud from the rest of mankind. Mr. Rucker. No, but Missouri does not elect any corrupted men to the bench" (Contributions to political committees in Presidential and other campaigns, 1906: 71).

However, these biblical motifs are used not so often in modern mass media as J.Wolcott wrote in one of his feature articles: "Popular culture no longer craves archangels and new dawns. Pop culture traffics in vampires and deads of night" (Wolcott, 2007). Using antithesis, 
this journalist makes an innuendo that common people like thrills, displaying negative emotions, and these thrills are where horror movies are shown.

\section{Four Horsemen of the Apocalypse}

According to the book of Revelation (Bucholtz, Kira, 1995:1-8), they emerge after the opening of 4 seals from 7 that leads to the Apocalypse. The first one, riding the white horse, symbolizes Christ; the second one, riding a red horse, looks like a symbol of bloodshed and war; the third one, riding a black horse, is identified as mass hunger; and the fourth horseman, riding a pale horse, looks like an envoy of death.

In 'Good Omens'(Pratchett, Gaiman, 1990), a comedy novel, written by T. Pratchett and N.Gaiman, we meet four persons incarnating four horsemen of the apocalypse. A military correspondent embodies War, a fast-food magnate personifies Famine, an inventor impersonates Pollution, and a biker exteriorizes Death. Instead of trying to change this world, they start trading their horses to buy new motorbikes. The key idea of their appearance, as well as the appearance of angel Aziraphale and demon Crowley, was expressed by Aziraphale: "We are here to lick some serious butt" (Pratchett, Gaiman, 1990). The application of Biblical motifs, the contrast between the religious depiction of four powerful horsemen of Apocalypse and their not serious behavior, creates the comic effect with elements of satire.

In 'Horseman'(Akerlund, 2009), a psychological thriller film, a group of serial killers looked like the images of four horsemen (War, Death, Conquest, Famine). Their motto was close to the phrase said by one of them called Kristin: "Death is what happens at the end. War is everything else" (Akerlund, 2009). Such stylistic figures as isocolon and hyperbole make this phrase impressive.

In American mass media, journalists have employed this biblical motif as well as this mighty metaphor quite often so far.

Such companies as Google, Amazon, Apple and Facebook are nicknamed as 'Four Horsemen of Tech.' The first journalist who called them so was L. Hower. In his opinion article, he writes: "The Four Horsemen of Tech. All have market capitalizations in the hundreds of billions. All dominate a giant category while having meaningful investments in emerging technology... Conventional wisdom has it that these four companies are unassailable in their core market...Conventional wisdom is wrong. Just rewind a few decades to see why" (Hower, 2017). Applying the powerful metaphor (4 horsemen of tech) making allusion on the biblical one and anaphora (all...all...conventional wisdom...conventional wisdom), this journalist creates an excellent example of literary journalism text.

In philology, American journalists found out 'The Four Horsemen of the Apocalypses in linguists' - P.Postal, J.R.Ross, G. Lakoff, and J.MacCawley. They made a big contribution in American philology, not forgetting to contradict Noam Chomsky, the founding father of modern American linguistics. The first researchers who called them so were M.Bucholtz and K.Hall: "This mini-revolution was made by 'Four Horsemen of the Apocalypse' - George Lakoff, James MacCawley, Paul Postal, and John Robert Ross..." (Bucholtz, 1995). They apply the impressive biblical metaphor, mixing it with the linguistic language and newspaper language, actualizing, in such a way, the stylistic figure pastiche.

Besides, in feature and opinion articles we can single out such metaphor as "Four Horsemen of Infocalypse." It relates to those criminals who use Internet for their fraud schemes: hackers, drug-dealers, money-launderers, etc. This phrase was introduced by Cyberpunk FAQ (May, 1994) who published some instructions for young hackers. 


\section{Three Wise Men}

In the Bible three Kings from the East visited Jesus right after his birth. They were described in the Gospel of Matthew going to Jerusalem to worship Jesus, the 'born King of Jews.' In the literature they could be mentioned like three magi, kings or wise men.

In 'The Gift of the Magi'(O'Henry, 1905), a short story, the biblical motif of 'three Wise Men' inspired the young couple in love to exchange Christmas gifts in spite of financial hardships. Though the story got an ironic ending, it turned into an eternal hymn of selfless and pure love.

In 'A Cosmic Christmas' (Smith, 1977), an animated cartoon, three aliens arrived to Earth to find out the true meaning of Christmas. Passing through sudden winter adventures, being invited in the house of Peter, a small boy, they understood the spirit of joy and forgiveness of this holiday. This story reveals the commercialism and hypocrisy circling around this holiday and at the same time it shows the true grains of it - family joy, mercy and love.

In modern mass media the biblical motif of 'three wise men' could be found out in blogs, feature stories and opinion articles. In one blog story, we find out the description of the Modern-day wise men from the Ministry coming to Sunday schools in such a way: "They come smiling, shaking hands, and giving gifts. I ask myself, 'Who are these people?'...Hope, joy, excitement enter" (Estioko, 2012). The Biblical motif is imposed on ironic description of rich charity people, but in the end the plot twist happens. These people are called metaphorically as hope, joy and excitement.

\section{Messiah or The Chosen One}

Messiah is a savior of some people or a group of peoples. In the Greek translation it sounds Kristos, in English variant - Christ. The Chosen one is a character favored by some (divine) force capable of solving some big and bad problem.

In literature the biblical motif of Messiah is well outlined in 'The Chronicles of Narvia'(Lewis, 1954), a series of fantasy novels. In the fifth book 'The Horse and His Boy'(1954), Aslan, the all-powerful and almighty lion calls himself Jesus: "Susan: But Aslan, how? Aslan: Because I am Jesus!" Though he says it in a solemn way, it sounds ironic.

In 'Harry Potter and the Deathly Hallows'(Rowling, 2007), the seventh fantasy book in the series, Harry, called by his wizard entourage as 'the Chosen One', decided to sacrifice himself in order to kill Voldemort. While destroying Horcrux within him, which connected Harry with Voldemort on the level of souls, he achieved the final death of the Chief wizard serving dark forces. However, in a while Harry preferred to resurrect himself.

In 'Good Omens'(Pratchett, N.Gaiman, 1990), a comedy novel, 'The Chosen One' turned out to be Antichrist who was accidentally switched at birth and was not so omnipotent. When the forces of Heaven and Hell got prepared for Armageddon, they found out that Antichrist was against the global war and asked just to forget the whole thing. The irony of the situation and the discrepancy between the Bible plot and the narrative variant with many twisted episodes lead to a comic end of the novel.

In 'The Matrix'(Washowskis, 1999), a science fiction film, Neo behaves as 'the Chosen One.' He is ready to fight with the Evil Matrix forces till the end of his life, saying, "I'll show these people what you don' want them to see. A world without rules and controls, without borders or boundaries. A world where anything is possible." Fighting like a warrior king he gets impressive victories, ready to sacrifice his life for the whole humanity.

In American mass media journalists ridicule Messiah complexes of some presidents. Once, D. Trump tweeted that he was 'the chosen one' to end China's unjust trade relations. 
Immediately CNN and MSNBC transmitted the news that D.Trump considered himself as Messiah. In a while, D.Trump informed that it was a joke (Linge, 2019).

In his satirical TV show, J. Leno cracked two jokes about Barack Obama: (a)"Barack Obama spent his first day as president-elect putting together his transition team. And if you believe MSNBC, by tomorrow he will have chosen all 12 of his disciples." (Leno, 2009). The comic effect is causes by such stylistic figures as pastiche (the mixture of the religious and political lexicon) and paraprosdokian (a sudden ending) underlying the Messiah complex of B.Obama. (b) "Q What's the difference between Obama and God? A: God does not think that he is Obama..." (Leno, 2009). In this joke the complex application of paraprosdokian, chiasmus and aposiopesis lead to the comic effect, stressing the Messiah complex of B.Obama once again.

\section{Saint Mary}

The virgin mother of Christ and the wife of Joseph was raised to the heaven by God after her earthly life belongs to the most respected biblical motifs in literature.

In 'Gone,'(Grant, 2008) a sci-fi novel, one of the characters called Mary became the most esteemed mother of children in the neighborhood getting the name 'Mother Mary' (Grant, 2008). An innuendo at the beginning of the novel turned into allusion on Saint Mary.

In 'Keeping Faith'(Picoult, 1999), a novel, a small girl Faith starts seeing God and angels attracting the attention of many people. Doing various miracles and healing desperately ill people, she gets in the hotspot or mass media. However, her own health deteriorates a lot. Just coming back to her mother Mariah, she recovers and becomes happy, not seeing anymore any religious visions. An innuendo is made that Saint Mary helped her to get a normal and happy life.

The biblical motif of Saint Mary could be noticed in various opinion articles and feature stories. So, one ABC journalist asks in his articles: "When a hyper-sexualized rap artist channels the most holy 'Mother of God,' is it blasphemy or art? 'It can be both, says Matthew Tan, a senior lecturer at University of Notre Dam'" (Hegarty, 2020). The dialogue sounds comic because of the usage of such stylistic figures as hyperbole (hyper-sexualized rap artist), anticlimax (blasphemy or art) and double entendre (it can be both.).

Famous pop singers address to Saint Mary in their songs and portray this divine image in their own way. So Beyoncé in her single 'Mine' dresses like Mother Mary and sings about her marital changes after the birth of a child. Rihanna in her studio album pleads to Virgin Mary in her song "Love without Tragedy/ Mother Mary.' The key line in her song, "Mother Mary, I swear I want to change." Singer Lana Del Rey takes the image of Mother Mary in the short film 'Tropico'(Gaba, 2021). It shows that Saint Mary biblical motif touches upon the souls of these modern singers and their audiences.

B. Obama, the 44th President of the USA, always carried a photo with words, "Mary Help of Christians, Pray for Us!" (Johnfea, 2010). It means that the biblical motif of Mother Mary helped B. Obama not only as a symbol of Christianity but also as an innuendo in all his speeches.

\section{Angel}

An Angel is a sacred celestial and supernatural creature in all religions. They are subordinate to God and his archangels and serve as mediators between people and Heaven. In American mass media we counted 136 names of angels, with the most frequently used: Abdiel, Appolyon, Imperius, Islington, Tyrael and some others (Encyclopedia, 2020). As for theological angels we found out 123 angels, the names of which are not always the same as the names of fiction and non-fiction angels (Context, 2021). 
In 'the Lords of the Rings' (Tolkien, 1954), a fantasy novel, one of the main characters Pippin reflects a lot about the origin of Gandalf who always supported the Good forces and used the ancient technique of wizardry. An innuendo is made that Gandalf in an old angel.

In 'Constantine'(Lawrence, 2005), a horror film, Constantine and Angela stand for the good and fight against the evil forces, keeping in mind that demonic creatures are very smart and slick: "Constantine: Detective. What if I told you that God and the Devil made a wager, a kind of standing bet for the souls of all mankind? Angela: I'd tell you to stay on meds. Constantine: Humor me. No direct contact with humans. That would be the rule. Just influence. See who would win. Angela: Ok, I'm humoring..." (Lawrence, 2005). The dialogue is based on biblical motifs and humorous remarks of Angela. An innuendo is made that celestial creatures avoid seeing people. In this film, such characters as Gabriel represents a 'half-breed' angel and Balthazar a 'half-breed' demon. However, the real fighters with Evil are Angela, a police officer, and Constantine, an occult detective. The innuendo is made that they keep sparkles of God in their souls and Angels is just an angel in a human body, though she does not know about it. As for Constantine, once he tried to commit suicide, that is why, he is punished with a serious illness.

President Joe Biden mentions Biblical angels in his public speeches before large audiences including leading journalists of the USA, "Our nation is shaped by the constant battle between our better angels and our darkest impulses... It is time for our better angels to prevail" (Haynes, 2020).

\section{Total number of angels and archangels in American mass media}

$\begin{array}{ll}\text { Celestial Beings } & \text { Tota } \\ \text { Archangels } & 17 \\ \text { Archangels in the Bible } & 7 \\ \text { Angels in fiction } & 136 \\ \text { Angels in theology } & 123\end{array}$

Besides, in this research we singled out such biblical motifs as 'All-Loving hero' used in 'Uncle Tom 's Cabin' novel by H.B.Stowe and in 'Idiot' novel written by F.Dostoevsky; 'Cain and Abel' employed in 'Gladiator' film directed by R.Scott, 'The Godfather' film part 2, directed by F.F.Coppola; 'Samson and Delilah' are hinted through allusions in 'Jane Eyre'novel by Charlotte Bronte, in 'Invisible Man'novel by R.Allison; 'False Prophet' applied in 'Last Battle' the seventh book of 'the Chronicles of Narvia' by C.S.Lewis, in 'Moby-Dick'novel by H.Melville; 'Nephilim' or 'giant' in 'Fallen' novel written by L.Kate, in 'Atlas Shrugged' by Ayn Grant.

\section{Conclusion}

The findings of this work illustrate that biblical motifs penetrate American fiction, non-fiction, its constituent part - literary journalism, public speeches. More than $73 \%$ of U.S. residents are Christians and their support is important for all high-rank state officials including Presidents of the USA.

Among the biblical motifs functioning in American literature, literary journalism as a part of non-fiction and public speeches, we singled out the most frequently used: God, All-Mighty, Lord, Supreme Being; Satan, Devil, Lucifier, Beelzebub, Baphomet; Saint Mary; Archangels; Angels; Four Horsemen of Apocalypses; The Three Wise Men; Messiah, the Chosen One; All-loving hero; Cain and Abel; Samson and Delilah; False prophet; Nephilim, giants. 
In American fiction and non-fiction, 136 names of angels are applied. As for the theological angels, whose names not always match the fictional ones, their number is 123 . As for the total number of Archangels, called in America mass media, it is 17, though in the Bible just only seven archangels are mentioned.

All presidents of the USA used the religious lexicon and biblical motifs in their public speeches relying on the Christian majority of American voters. Since Ronald Reagan (1981-1989), there has been an obvious trend for applying more religious words and phrases. The most frequent users of the religious words and phrases were Donald Trump, George H.W. Bush, and Barack Obama who used 7.3, 4.8, and 4.1 religious words per thousand, respectively, in their speeches.

The findings of this work could be employed by media studies specialists, journalists and linguists, as well as by practicing journalists and multimedia authors, including students, who plan to sharpen their skills in writing English content.

\section{References}

1. AkerlundJ. (2009). Horsemen. Apsychological thrillerfilm. Mandate Pictures. Retrieved from: https://www.moviefone.com/movie/horsemen/36111/where-to-watch/(access 02/01/2021).

2. Azimov I. (1955).The Last Trump. Sci-fi story. Fantastic Universe. Retrieved from: https://thefreenovelsread.com/243246-the-complete-stories (acess 29/01/2021).

3. Azimov.I. (1953).Flies. Sci-fi short story. Magazine of fantasy and Science-fiction. Retrieved from: https://archive.org/stream/Fantasy_Science_Fiction_v004n06_1953-06/ Fantasy_Science_Fiction_v004n06_1953-06\#page/n17/mode/2up (access 31/01/2021).

4. Bak, J. S., \& Reynolds, B. (Eds.). (2011). Literary Journalism Across the Globe: Journalistic Traditions and Transnational Influences. Boston, MA: University of Massachusetts Press.

5. BBC News. (08/02/2016). Trump calls Clinton 'the devil.' Retrieved from: https://www.bbc.com/news/av/world-us-canada-36949974 (access 02/03/2021).

6. Bucholtz M., Kira H. (1995). "Introduction: Twenty Years after Language and Woman's Place. Gender Articulated. Language and the Socially Constructed Self. New York and London: Routledge. 200 p. ISBN 0-415-91398-5.

7. Coe K., Domke D. (2006). Petitioners or prophets? Presidential discourse, God, and the ascendancy of religious conservatives. Journal of Communication, 56, 309-330 p.

8. Context of list of fictional angels. List of angels in theology (2021). Retrieved from: http://discovery.nifty.works/ (access 02/03/2021).

9. Contributions to political committees in Presidential and other campaigns. (1906). Colombia University Libraries. Retrieved from: https://books.google.com.ua/books?id=p1lKAAAAYAA$J \& p g=P A 71 \& l p g=P A 71 \& d q=$ presidents + mention + archangels (access 29/01/2021).

10. Encyclopedia Wikipedia (04/20/2021). List of angels in fiction. Retrieved from: https:/len.wikipedia.org/wiki/List_of_angels_in_fiction (access: 02/01/2021).

11. Estioko E. (12/25/2012). Modern-day Wise Men. Blog article. Retrieved from: https://blog.compassion.com/modern-day-wise-men/ ( access 02/01/2021).

12. Forgey Q.(08/07/ 2020) 'Shameful': Biden slams Trump for saying he would 'hurt God' if elected. Article. Retrieved from: https://www.politico.com/news/2020/08/07/joe-biden-slamstrump-religion-392550 (access 01/30/2021)

13. Gaba s. (2021).Pop culture and the Virgin Mary. Retrieved from: https://www.beliefnet. com/entertainment/galleries/pop-culture-and-the-virgin-mary.aspx (access 02/01/2021). 
14. Garcia V. (2007). Return to house on Hinted Hill. Horror film. Warner Premiere. Retrieved from: $\quad$ https://ww3.9movies.yt/watch/return-to-house-on-haunted-hill-25064/?ep=93466 (access 29/01/2021)

15. Gladwell. M. (2021). What is a motif? Article. Retrieved from: https://www.masterclass. com/articles/writing-101-what-is-a-motif\#5-famous-examples-of-motifs (access 30.01.2021).

16. Grant M.(2008).Gone. Sci-fi and thriller novel. USA.HarperCollins. P. 2005.

17. Haynes D.D. (11/12/2020) Opinion: President-elect Joe Biden is summoning our better angels. Will we listen? Article. Retrieved from: https://www.jsonline.com/story/news/ solutions/2020/11/12/president-elect-joe-biden-summoning-our-better-angels/6245529002/ (access 29/01/2021)

18. Hegarty S. (10/30/2020). From Nicki Minaj to FrankenMary, the Virgin Mary keeps on appearing in pop culture. This is why. Article. Retrieved from: https://www.abc.net.au/news/2020-08-30/sexualised-nicki-minaj-beyonce-catholic-virgin-mary-pop-culture/12598216 (access 02.01.2021)

19. Hughes C. (10/13/2020). The conversation. Retrieved from: https://theconversation.com/ appealing-to-evangelicals-trump-uses-religious-words-and-references-to-god-at-a-higherrate-than-previous-presidents (access 01/30/2021).

20. Hower L., Hunting the Four Horsemen of Tech, published 5 May 2017, URL: https://medium.com/swlh/hunting-the-four-horsemen-of-tech-4cb82be7e8a2 (access 29/01/2021). 21. Johnfea J. (09/29/2010). Barack Obama and the Virgin Mary. Article. Retrieved from: https://thewayofimprovement.com/2010/09/29/barack-obama-and-the-virgin-mary/(access 03/02/2021).

22. Keeble R.L. (7/30/2018) Literary Journalism. Article. Retrieved from: https://oxfordre.com/view/10.1093/acrefore/9780190228613.001.0001/acrefore9780190228613-e-836(access 03/06/2021).

23. Lawrence.F.(2005).Constantine. Horror film. Warner Bros. URL: https://www.hungama. com/movie/constantine/22417024/ (access:02/01/2021).

24. Lawson, Mark. (2008, April 5). I heard the news today, oh boy. Guardian. Retrieved from:

25. https://www.theguardian.com/books/2008/apr/05/featuresreviews.guardianreview21(retrieved 07.02.2020)

26. Leiro S.(02/04/2016). President Obama: "Faith is the great cure for fear". Opinion article. URL: https://obamawhitehouse.archives.gov/blog/2016/02/04/president-obama-faith-greatcure-fear (acccess 329/01/2021).

27. Leno J. (2009). Barack Obama Jokes. Retrieved from: http://politicalhumor.about.com/od/ barackobama/Barack_Obama_Jokes.htm (access 11.11.2020).

28. Lewis C.S. (1954).The Horse and His boy. Children fantasy novel. UK. Geoffrey Bles. P.199.

29. Linge M.K. (08/24/2019) Trump says that was just joking about the 'chosen one.' News article. URL: https://nypost.com/2019/08/24/trump-says-he-was-just-joking-about-being-thechosen-one/(access 02.01.2021).

30. May T. C. (1994-09-10). "\$8.3.4. How will privacy and anonymity be attacked?". The Cyphernomicon. Retrieved from: http://groups.csail.mit.edu/mac/classes/6.805/articles/crypto/ cypherpunks/cyphernomicon/CP-FAQ (access 02/01/2021).

31. Milton J.(1667). Paradise Lost. Epic poem. Sammuel Wilson, P.135. Retrieved from: https://www.poetryfoundation.org/poems/45718/paradise-lost-book-1-1674-version (access 29/01/2021) 
32. Newport F (2017). 2017 Update on Americans and Religion. Retrieved from: https://news. gallup.com/poll/224642/2017-update-americans-religion.aspx (access 12/22/2017).

33. Nordquist R. (2020). What is literary journalism? Article. URL: https://www.thoughtco.com/what-is-literary-journalism-1691132(retrieved 7.02.2020)

34. O'Henry. (1905). The Gift of Magi. Short story. Retrieved from: http://webhome.auburn.edu/ vestmon/Gift_of the_Magi.html (access: 02/01/2021).

35. Peters G.H., Woolley J.T. (2018). The American Presidency Project. The Presidential documents on the Internet. Retrieved from: https://www.presidency.ucsb.edu/ (access: 03/02/2021). 36. Picoult J.(1999). Keeping Faith. Novel.USA.William Morrow.P.432.

37. Pratchett T., Gaiman N. (1990). Good Omens. Horror, fantasy, comedy novel. UK,Gollanz. P. 288 p.

38. Reagan R. (03/08/1983)."Ronald Reagan, Address to the National Association of Evangelicals ("Evil Empire Speech")". Voices of Democracy: The U.S. Oratory Project. University of Maryland, College Park. March 8, 1983.

39. Rowling J.K.(2007). Harry Potter and the Deathly Hallows. Fantasy book. UK. Bloomsbury. P.607

40. Smith C.A. (1977). A Cosmic Christmas. Animated cartoon. CBC. Retrieved from: https://www.youtube.com/watch? $v=k 7 x W-v V X 74$ s (access: 02/01/2021).

41. Tolkien J.R.R. (1954). The Lords of the Rings. Epic fantasy novel. UK. Allen \&Unwin. P. 1216.

42. Washowskis T. (1999).The Matrix. Science fiction action film. Retrieved from: https://www.digit.in/digit-binge/movies/the-matrix-6455.html (retrieved 02.01.2021).

43. Wolcott. J. (2007). BrainyQuotes. Retrieved from: https://www.brainyquote.com/search_ results?q=archangel (access 29/01/2021).

44. Wolfe, T., \& Johnson, E. W. (Eds.). (1975). The New Journalism. London, UK: Picador, 1975, $394 p$. 